\title{
Efficacy of 2,4-D Choline/Glyphosate Dimethylamine on Glyphosate Resistant Canada Fleabane (Conyza canadensis) at Different Sizes
}

\author{
Laura Ford, Nader Soltani*, Darren E. Robinson, Robert E. Nurse, Allan McFadden, \\ Peter H. Sikkema \\ University of Guelph, Ridgetown Campus, Ridgetown, Canada \\ Email: ${ }^{*}$ soltanin@uoguelph.ca
}

Received 29 May 2014; revised 16 July 2014; accepted 10 August 2014

Copyright (C) 2014 by authors and Scientific Research Publishing Inc.

This work is licensed under the Creative Commons Attribution International License (CC BY).

http://creativecommons.org/licenses/by/4.0/

c) (i) Open Access

\begin{abstract}
Glyphosate resistant (GR) Canada fleabane has spread quickly across southwestern Ontario and new strategies for the control of this competitive weed must be developed especially in no-tillage crops. A premix of 2,4-D choline and glyphosate dimethylamine (DMA) has been developed for application on tolerant corn, soybean and cotton crops that provides an option for the control of this problematic GR weed. The objective of this research was to determine the required dose needed to effectively control GR Canada fleabane at different size categories in field and greenhouse experiments. In the field experiments, nine rates of 2,4-D choline/glyphosate DMA (53.8 to 13,760 $\mathrm{g} \cdot \mathrm{ae} \cdot \mathrm{ha}^{-1}$ ) were applied to GR Canada fleabane that were $10 \mathrm{~cm}$ in diameter/tall, $20 \mathrm{~cm}$ tall or 30 cm tall. Similarly, in the greenhouse, seven rates of 2,4-D choline/glyphosate DMA (0 to 3440 $\mathrm{g} \cdot \mathrm{ae} \cdot \mathrm{ha}^{-1}$ ) were applied to 10,20 and $30 \mathrm{~cm}$ tall GR Canada fleabane plants. The three different size classes of GR Canada fleabane responded similarly to 2,4-D choline/glyphosate DMA in the field experiment. In the greenhouse there were some differences in control for the three size classes of GR Canada fleabane with 2,4-D choline/glyphosate DMA; the 20 and $30 \mathrm{~cm}$ tall plants required similar rates to provide equivalent control, but the $10 \mathrm{~cm}$ plants required a lower rate. In all situations, greater than $1720 \mathrm{~g} \cdot \mathrm{ae} \cdot \mathrm{ha}^{-1}$ of 2,4-D choline/glyphosate DMA was required to provide $95 \%$ control of 10,20 and $30 \mathrm{~cm}$ tall Canada fleabane in greenhouse (35 DAA) and field experiments (8 WAA), respectively.
\end{abstract}

\section{Keywords}

Glyphosate Resistance, Multiple Herbicide-Resistant Crops, Preplant Herbicides, Postemergence Herbicides

\footnotetext{
${ }^{*}$ Corresponding author.
}

How to cite this paper: Ford, L., Soltani, N., Robinson, D.E., Nurse, R.E., McFadden, A. and Sikkema, P.H. (2014) Efficacy of 2,4-D Choline/Glyphosate Dimethylamine on Glyphosate Resistant Canada Fleabane (Conyza canadensis) at Different Sizes. American Journal of Plant Sciences, 5, 2755-2763. http://dx.doi.org/10.4236/ajps.2014.518292 


\section{Introduction}

Glyphosate resistant (GR) Canada fleabane [Conyza canadensis (L.) Cronq.] was first discovered in Ontario, Canada in 2010 at eight sites in Essex County [1]. By 2012, 155 sites in eight Ontario counties had been confirmed with GR Canada fleabane [1]. Glyphosate resistant Canada fleabane has spread rapidly across southwestern Ontario because of its fecundity (up to 1 million seeds/plant) [2] and the long pappus attached to the small seed (1.3 mm long by $0.3 \mathrm{~mm}$ wide) which allows the seed to be wind dispersed up to $500 \mathrm{~km}$ from the parent population [3] [4]. Canada fleabane is well adapted to no-tillage crop production systems because its germination success is the greatest when the seed is on the soil surface [2]. Canada fleabane begins growth as a rosette and bolts later in the growing season, reaching up to $180 \mathrm{~cm}$ in height [5]. Canada fleabane seeds can germinate year round, with the majority of seeds germinating in autumn and overwintering as a rosette and a smaller proportion of seeds germinating in the spring; this prolonged germination makes herbicide application timing very difficult [6].

With the development of GR weeds, older herbicide modes of action, including 2,4-D, are being used for control. The herbicide, 2,4-D, was developed during the 1940s and provides control of broadleaf weeds [7]. Although the first herbicide resistant weed was 2,4-D resistant wild carrot (Daucus carota L.) in the 1950s there are only 17 species resistant to 2,4-D today [8]. Wild carrot is the only specie in Ontario that has previously been found to be resistant to 2,4-D [8]. 2,4-D is a growth hormone that causes the transcription of genes that are normally repressed leading to uncontrolled plant growth and eventually plant death [9]. This herbicide is rapidly broken down in the soil within 17 - 38 days, and therefore does not provide long residual activity [10]. One concern with the use of 2,4-D, is that it may result in injury to sensitive crops in adjacent fields because it is volatile and can result invapour drift [11] [12]. The 2,4-D ester formulation is more volatile than the 2,4-D amine [13]. The 2,4-D choline formulation is designed and has demonstrated to be less volatile as well [9]. The 2,4-D choline formulation will be sold in a pre-mix with glyphosate (dimethylamine) DMA [9]. The combination of the choline salt with the manufacturer's formulation science of this herbicide has resulted in $88 \%-96 \%$ less vapour loss compared to other forms of 2,4-D [14]. The 2,4-D choline/glyphosate DMA formulation combined with coarse droplet sized nozzle tips has resulted in 90\% less drift compared to a tank mix of 2,4-D amine and glyphosate applied with medium droplet sized nozzle tips [14]. The 2,4-D choline/glyphosate DMA pre-mix herbicide will be introduced in combination with soybean, cotton and corn cultivars/hybrids that are resistant to this herbicide pre-mix [9]. Some other positive attributes of this new formulation include a reduction in odour, and an increase in stability at cold storage temperatures [9]. The 2,4-D choline/glyphosate DMA pre-mix also reduces tank mix problems that can occur with other salt formulations, for example 2,4-D amine combined with potassium salt formulation of glyphosate produces a precipitate that clogs nozzles [9].

The labelled rate of the 2,4-D choline/glyphosate DMA in Canada will be $1720 \mathrm{~g} \cdot \mathrm{ae}^{\mathrm{h}} \mathrm{ha}^{-1}$ which includes 840 $\mathrm{g} \cdot \mathrm{ae} \cdot \mathrm{ha}^{-1}$ of 2,4-D and $880 \mathrm{~g} \cdot \mathrm{ae}^{-\mathrm{ha}^{-1}}$ of glyphosate. There have been conflicting reports in the literature on the effect of Canada fleabane size on 2,4-D efficacy. Kruger et al. [15] reported that 2,4-D ester and amine (560 $\mathrm{g} \cdot \mathrm{ae} \cdot \mathrm{ha}^{-1}$ ) provided equivalent control (90\%) of Canada fleabane at 0.5 to $30 \mathrm{~cm}$ in height. However, Kruger et al. [16] found that 2,4-D amine applied to Canada fleabane over $30 \mathrm{~cm}$ in height provided 81\% control. Keeling et al. [17] found that 2,4-D ester (600 g·ae $\cdot \mathrm{ha}^{-1}$ ) provided $97 \%$ and $50 \%-60 \%$ control of rosette sized (less than $10 \mathrm{~cm}$ ) and 10 - $15 \mathrm{~cm}$ tall Canada fleabane, respectively. These studies show variable control of Canada fleabane with 2,4-D ester and amine. In addition, Kruger et al. [16] reported that the various salt formulations of 2,4-D and dicamba influence efficacy on GR Canada fleabane biotypes differently. These studies show variable control of Canada fleabane with 2,4-D ester. Consequently, it is important to determine the efficacy of 2,4-D choline/glyphosate DMA applied to Canada fleabane at different sizes.

The objective of this research was to determine the required dose of 2,4-D choline/glyphosate DMA needed to effectively control GR Canada fleabane at 10, 20 and $30 \mathrm{~cm}$ height.

\section{Materials and Methods}

\subsection{Greenhouse Studies}

This experiment was repeated twice in the summer of 2012 with four replications for each run. The replications were randomly arranged in the greenhouse to ensure lighting was similar for the three size classes of Canada fleabane. Seven rates of 2,4-D choline/glyphosate DMA (0, 107.5, 215, 430, 860, 1720, 3440 g·ae·ha $\left.{ }^{-1}\right)$ were $^{2}$ 
applied to three different size classes of Canada fleabane, 10, 20 and $30 \mathrm{~cm}$ tall plants. Plants of each size were transplanted from a field near Leamington that had been confirmed resistant in 2011 [1]. These plants were placed in the greenhouse and given a chance to recover from the transplant shock before the herbicide treatments were applied. This experiment was conducted in the summer and therefore only natural light was used, with the shade cloth across, the photoperiod during this time of the year was $16 \mathrm{~h}$ of natural light. The GR Canada fleabane was watered with tap water after transplanting and every morning for the duration of the experiment, fertilizer was not applied.

The plants were sprayed with the different rates of 2,4-D choline/glyphosate DMA in a chamber sprayer with a single 80-02 flat fan nozzle. The spray chamber shelf was adjusted for the different sized plants, so that the top of the canopy was $45 \mathrm{~cm}$ below the spray nozzle. The spray chamber was set at $2.15 \mathrm{~km} \cdot \mathrm{h}^{-1}$ with a pressure of $280 \mathrm{kPa}$. Control ratings were taken 1, 7, 14, 21 and 35 days after the application (DAA). At day 35, any living plants were harvested at the soil line, placed in the dryer at $60^{\circ} \mathrm{C}$ (approx. 2 weeks), and the dry weight was recorded.

\subsection{Field Studies}

Field trials were completed over two summers (2012 and 2013) at Ontario farms with confirmed glyphosate resistant (GR) Canada fleabane [1]. There were six sites in total; three sites near Harrow (L2, L3, and L5), two near Windsor (L1 and L6) and one near Ridgetown (L4). At each of these six sites, three experiments were established where nine rates of 2,4-D choline/glyphosate DMA (53.8, 107.5, 215, 430, 860, 1720, 3440, 6880 or $13,760 \mathrm{~g} \cdot \mathrm{ae} \cdot \mathrm{ha}^{-1}$ ) were applied to Canada fleabane that were 10,20 or $30 \mathrm{~cm}$ tall. The diameter/height was used for the $10 \mathrm{~cm}$ trial because if the plant bolted before it reached $10 \mathrm{~cm}$ in diameter the height was used. The 10 cm Canada fleabane experiment from the L3 site (Harrow) in 2012 was moved to the Windsor location (L1), due to limited space at the Harrow location. Roundup Ready corn was no-tilled at all sites in the spring. Soil samples were taken and characteristics for each site are summarized in Table 1.

All three experiments were established using a randomized complete block design with four replications. Experimental units were $2.5 \mathrm{~m}$ wide by $8 \mathrm{~m}$ long, with a $2 \mathrm{~m}$ walkway between each replication. There was an untreated (weedy) and weed-free control in each replication. The treatment timing was dependent on the Canada fleabane size and not the corn growth stage; application date and corn growth stage at the time of the application are summarized in Table 2. Herbicide treatments were applied using a $\mathrm{CO}_{2}$-pressurized backpack sprayer calibrated to deliver $200 \mathrm{~L} \cdot \mathrm{ha}^{-1}$ at $240 \mathrm{kPa}$. The boom was $1.5 \mathrm{~m}$ long with four ultra-low drift nozzles (ULD120-02, Hypro, New Brighton, MN) spaced $50 \mathrm{~cm}$ apart.

Canada fleabane control ratings were based on a $0 \%-100 \%$ scale, 0 meaning no control and 100 meaning complete control. Canada fleabane control ratings occurred 1, 2, 4, and 8 WAA. At 8 WAA, weed counts and weed harvests were taken using two $0.25 \mathrm{~m}^{2}$ quadrats/treatment, the Canada fleabane in each quadrat was counted and cut at the soil surface. These samples were dried at $60^{\circ} \mathrm{C}$, and the dry weight was recorded.

Table 1. Location information, soil characteristics, crop description and planting date for the application of 2,4-D choline/ glyphosate DMA choline on different sizes of Canada fleabane $(10 \mathrm{~cm}, 20 \mathrm{~cm}$ and $30 \mathrm{~cm}$ tall) conducted in field trials in 2012 and 2013.

\begin{tabular}{|c|c|c|c|c|c|c|c|c|c|}
\hline Location $^{z}$ & Year & Nearest town & Soil texture & $\begin{array}{c}\text { Soil \% } \\
\text { OM }\end{array}$ & Soil pH & Planting date & Corn hybrid & $\begin{array}{c}\text { Planting } \\
\text { population } \\
\left(\text { seeds } h^{-1} \text { ) }\right.\end{array}$ & $\begin{array}{l}\text { Row } \\
\text { spacing } \\
\text { (cm) }\end{array}$ \\
\hline L1 & 2012 & Windsor & Sandy loam & 2.5 & 6.7 & 18-Мay-12 & P0118AR & 46930 & 76.2 \\
\hline L2 & 2012 & Harrow & Loam & 3.3 & 7.2 & 04-May-12 & P0245 & 83900 & 76.2 \\
\hline L3 & 2012 & Harrow & Loam & 3.3 & 7.2 & 04-May-12 & P0245 & 83900 & 76.2 \\
\hline L3 - $10 \mathrm{~cm}$ trial & 2012 & Windsor & Sandy loam & 2.5 & 6.7 & 18-Маy-12 & P0118AR & 46930 & 76.2 \\
\hline L4 & 2013 & Ridgetown & Loam & 2.2 & 5.7 & 15-May-13 & P 35F50 & 79781 & 96.5 \\
\hline L5 & 2013 & Harrow & Sandy loam & 1.4 & 7.5 & 22-Мay-13 & DK 49-94 RIB & 79040 & 76.2 \\
\hline L6 & 2013 & Windsor & Clay loam & 2.6 & 7.2 & 07-Jun-13 & DK 49-94 RIB & 79040 & 76.2 \\
\hline
\end{tabular}

\footnotetext{
${ }^{\mathrm{z}}$ Abbreviations: RIB is refuge in the bag; OM is organic matter.
} 
Table 2. Application date, corn growth stage at the time of the application and the density of Canada fleabane across the field sites in 2012 and 2013.

\begin{tabular}{|c|c|c|c|c|c|c|c|c|c|c|}
\hline Location $^{z}$ & Year & $\begin{array}{l}\text { Application } \\
\text { date } 10 \mathrm{~cm}\end{array}$ & $\begin{array}{c}\text { Application } \\
\text { date } 20 \mathrm{~cm}\end{array}$ & $\begin{array}{c}\text { Application } \\
\text { date } 30 \mathrm{~cm}\end{array}$ & $\begin{array}{l}\text { Corn stage } \\
\text { at } 10 \mathrm{~cm}\end{array}$ & $\begin{array}{l}\text { Corn stage } \\
\text { at } 20 \mathrm{~cm}\end{array}$ & $\begin{array}{c}\text { Corn stage } \\
\text { at } 30 \mathrm{~cm}\end{array}$ & $\begin{array}{c}\text { Density } \\
10 \mathrm{~cm} \\
\left(\# \mathrm{~m}^{-2}\right)\end{array}$ & $\begin{array}{c}\text { Density } \\
20 \mathrm{~cm} \\
\left(\# \mathrm{~m}^{-2}\right)\end{array}$ & $\begin{array}{c}\text { Density } \\
30 \mathrm{~cm} \\
\left(\# \mathrm{~m}^{-2}\right)\end{array}$ \\
\hline L1 & 2012 & 14-May-12 & 30-May-12 & 8-Jun-12 & Preplant & $3 \mathrm{LF}$ & $4 \mathrm{LF}$ & 920 & 112 & 332 \\
\hline L2 & 2012 & 18-Apr-12 & 1-May-12 & 17-May-12 & Preplant & Preplant & $2 \mathrm{LF}$ & 12 & 12 & 12 \\
\hline L3 & 2012 & - & 8-May-12 & 23-May-12 & - & Preemergence & $4 \mathrm{LF}$ & - & 6 & 21 \\
\hline L3 - $10 \mathrm{~cm}$ trial & 2012 & 17-May-12 & - & - & Preplant & - & - & 86 & - & - \\
\hline L4 & 2013 & 9-May-13 & 29-May-13 & 17-Jun-13 & Preplant & $2 \mathrm{LF}$ & $7 \mathrm{LF}$ & 134 & 47 & 70 \\
\hline L5 & 2013 & 30-Apr-13 & 14-May-13 & 30-May-13 & Preplant & Preplant & Spike & 35 & 154 & 363 \\
\hline L6 & 2013 & 19-Jun-13 & 26-Jun-13 & 3-July-13 & $2-3 \mathrm{LF}$ & $3-4 \mathrm{LF}$ & $6 \mathrm{LF}$ & 23 & 19 & 21 \\
\hline
\end{tabular}

${ }^{\mathrm{z}}$ Abbreviations: L1, L6 are windsor; L2, L3 and L5 are harrow; L4 is ridgetown; LF is leaf.

\subsection{Statistical Analysis}

The data were subjected to an ANOVA using the PROC MIXED procedure in the SAS 9.1 program. Variance of Canada fleabane control for each size $(10,20,30 \mathrm{~cm})$ was partitioned into fixed effects (herbicide treatment) and random effects (environment/run (for greenhouse), replication within environment/run and treatment by environment/run interactions). A Type 1 error rate of 0.05 was used for all statistical tests. Z-tests were used to determine the significance of the random effects and F-tests were used to test the significance of the fixed effects. The significance of the environment/run by treatment interaction was used to determine if the sites could be combined. The assumptions of the analysis (errors are random, homogenous, independent of effects and normally distributed) were examined by plotting the residuals as well as examining the Shapiro-Wilk test of normality. If necessary, a transformation of the data (natural log, square root or arcsine square root) was applied to help meet the assumptions.

A non-linear regression analysis was conducted on all data using the PROC NLIN procedure in the SAS 9.1 (SAS Institute, Cary, NC). The I50 values were compared to determine if there was a difference in control with 2,4-D choline/glyphosate DMA when applied to different sizes of Canada fleabane. The log-logistic model was used [18]:

$$
\mathrm{Y}=\mathrm{C}+\frac{\mathrm{D}-\mathrm{C}}{1+\exp [\mathrm{b}(\log (\mathrm{X})-\log (\mathrm{I} 50))]}
$$

In this equation Y stands for the percent control of Canada fleabane, $\mathrm{C}$ is the lower limit, $\mathrm{D}$ is the upper limit, $\mathrm{b}$ is the slope of the line (negative for control, positive for dry weight and density) and the I50 is the rate that provides a 50\% response between the upper and lower limits [18]. The ED50, 80 and 95 represent the rate that provides 50\%, $80 \%$ and $95 \%$ control of Canada fleabane, respectively. These values were determined by entering 50, 80 and 95 as the $\mathrm{Y}$ value and plugging the D, C, B and I50 values from the PROC NLIN procedure to solve for $\mathrm{X}$ or the rate. For the dry weight and density 50, 20 and 5 were used as the $\mathrm{Y}$ values.

\section{Results and Discussion}

\subsection{Greenhouse Studies}

The D values (upper limit) 1 day after application (DAA) of 2,4-D choline/glyphosate DMA on $10 \mathrm{~cm}, 20 \mathrm{~cm}$ and $30 \mathrm{~cm}$ tall Canada fleabane plants were 100, 46 and 46, respectively (Tables 3-5). The I50 values 1 DAA, varied as well, 52,093, 335 and 965 for the 10, 20 and $30 \mathrm{~cm}$ trials, respectively (Tables 3-5). To achieve 50\%, 80\% and 95\% control 1 DAA of 2,4-D choline/glyphosate DMA on $10 \mathrm{~cm}$ tall Canada fleabane a rate greater than the highest rate applied, $3440 \mathrm{~g} \cdot \mathrm{ae} \cdot \mathrm{ha}^{-1}$, was needed (Table 3). There were no rates 1 DAA of 2,4-D choline/glyphosate DMA applied to $20 \mathrm{~cm}$ and $30 \mathrm{~cm}$ tall plants that provided $50 \%$, 80\% or $95 \%$ control of the Canada fleabane (Table 4, Table 5). The application of 2,4-D choline/glyphosate DMA on $10 \mathrm{~cm}$ tall plants at 7 DAA had a lower I50 value of 190 compared to the $20 \mathrm{~cm}$ trial, 5132, and $30 \mathrm{~cm}$ trial, 3747 (Tables 3-5). At 7 DAA, the rate of 2,4-D choline/glyphosate DMA required to provide $50 \%$ and $80 \%$ control of $10 \mathrm{~cm}$ tall Canada 
Table 3. The rate response for the control of $10 \mathrm{~cm}$ tall glyphosate resistant Canada fleabane with 2,4-D choline/glyphosate DMA 1, 7, 14, 21 and 35 days after application (DAA) and dry weight data in controlled environment experimentsin 2012.

\begin{tabular}{ccccccccc}
\hline Rate response $^{\mathrm{v}}$ & Run & $\mathrm{D}^{\mathrm{z}}$ & $\mathrm{C}$ & $\mathrm{B}^{\mathrm{y}}$ & $\mathrm{I}^{\mathrm{x}}$ & ED50 $^{\mathrm{w}}$ & ED80 & ED95 \\
\hline 1 DAA & R1 and R2 & $100(0)$ & $0.2(1.4)$ & $0.2(0)$ & $52,093(24455)$ & $>13,760$ & $>13,760$ & $>13,760$ \\
7 DAA & R1 and R2 & $100(0)$ & $0(0.0)$ & $0.4(0.1)$ & $190(54)$ & 190 & 9624 & $>13,760$ \\
14 DAA & R1 and R2 & $100(0)$ & $0.1(0.3)$ & $0.5(0.1)$ & $648(138)$ & 645 & 10334 & $>13,760$ \\
21 DAA & R1 and R2 & $100(0)$ & $0(0)$ & $0.6(0.1)$ & $175(39)$ & 175 & 1767 & $>13,760$ \\
35 DAA & R1 and R2 & $100(0)$ & $0.8(6.0)$ & $0.9(0.2)$ & $638(137)$ & 627 & 2944 & $>13,760$ \\
Dry weight & R1 and R2 & $100(1)$ & $24.8(1.0)$ & $1.3(1.4)$ & $62(45)$ & 143 & - & - \\
\hline
\end{tabular}

${ }^{\mathrm{z}} \mathrm{D}$ is the upper limit and $\mathrm{C}$ is the lower limit; ${ }^{\mathrm{y}} \mathrm{B}$ is the slope of the line; ${ }^{\mathrm{x}} \mathrm{I} 50$ is the rate where there is a $50 \%$ response; ${ }^{\mathrm{w}} \mathrm{ED}=$ the rate of 2,4-D choline/glyphosate DMA where there is $50 \%, 80 \%$ and $95 \%$ control; ${ }^{\mathrm{v}}$ Abbreviations: DAA, days after application; R1 and R2 are the two runs of this experiment.

Table 4. Rate response for the control of $20 \mathrm{~cm}$ tall glyphosate resistant Canada fleabane with 2,4-D choline/glyphosate DMA 1, 7, 14, 21 and 35 DAA and dry weight data at 35 DAA in controlled environment experiments in 2012.

\begin{tabular}{ccccccccc}
\hline Rate response $^{\mathrm{v}}$ & Run & $\mathrm{D}^{\mathrm{z}}$ & $\mathrm{C}$ & $\mathrm{B}^{\mathrm{y}}$ & $\mathrm{I}^{\mathrm{x}}$ & ED50w & ED80 & ED95 \\
\hline 1 DAA & R1 and R2 & $46(15)$ & $0(0)$ & $0.5(0.2)$ & $335(469)$ & - & - & - \\
7 DAA & R1 and R2 & $100(0)$ & $0(0.1)$ & $0.3(0.0)$ & $5132(1403)$ & 5132 & $>13,760$ & $>13,760$ \\
14 DAA & R1 and R2 & $100(0)$ & $0(0)$ & $0.5(0)$ & $220(31)$ & 220 & 3660 & $>13,760$ \\
21 DAA & R1 and R2 & $100(0)$ & $0(0)$ & $0.5(0.1)$ & $271(46)$ & 271 & 3444 & $>13,760$ \\
35 DAA & R1 and R2 & $100(0)$ & $1.1(3.4)$ & $0.8(0.1)$ & $702(91)$ & 683 & 3543 & $>13,760$ \\
Dry weight & R1 and R2 & $98(8)$ & $0(0)$ & $0.6(0.2)$ & $1084(448)$ & 3305 & $>13,760$ & $>13,760$ \\
\hline
\end{tabular}

${ }^{\mathrm{z}} \mathrm{D}$ is the upper limit and $\mathrm{C}$ is the lower limit; ${ }^{\mathrm{y}} \mathrm{B}$ is the slope of the line; ${ }^{\mathrm{x}} \mathrm{I} 50$ is the rate where there is a $50 \%$ response; ${ }^{\mathrm{w}} \mathrm{ED}=\mathrm{the}$ rate of glyphosate/2,4-D choline where there is $50 \%, 80 \%$ and $95 \%$ control; ${ }^{\mathrm{v}}$ Abbreviations: DAA, days after application; R1 and R2 are the two runs of this experiment.

Table 5. Rate response for the control of $30 \mathrm{~cm}$ tall glyphosate resistant Canada fleabane with 2,4-D choline/glyphosate DMA 1, 7, 14, 21 and 35 DAA and dry weight data at 35 DAA in controlled environment in 2012.

\begin{tabular}{ccccccccc} 
Rate response $^{\mathrm{v}}$ & Run & $\mathrm{D}^{\mathrm{z}}$ & $\mathrm{C}$ & $\mathrm{B}^{\mathrm{y}}$ & $\mathrm{I}^{\mathrm{x}}$ & ED50 $^{\mathrm{w}}$ & ED80 & ED95 \\
\hline 1 DAA & R1 and R2 & $46(14)$ & $0(0)$ & $0.6(0.2)$ & $965(1047)$ & - & - & - \\
7 DAA & R1 and R2 & $94(38)$ & $0(0)$ & $0.4(0.1)$ & $3747(7396)$ & 5238 & $>13,760$ & - \\
14 DAA & R1 and R2 & $100(0)$ & $0.1(0)$ & $0.6(0.1)$ & $346(45)$ & 345 & 3215 & $>13,760$ \\
21 DAA & R1 and R2 & $100(0)$ & $1.0(3.4)$ & $0.9(0.1)$ & $987(127)$ & 965 & 4651 & $>13,760$ \\
35 DAA & R1 and R2 & $100(0)$ & $0.2(0.4)$ & $0.8(0.1)$ & $708(125)$ & 704 & 4424 & $>13,760$ \\
Dry weight & R1 and R2 & $89(5)$ & $0(0)$ & $1.3(0.4)$ & $2499(512)$ & 3933 & 8045 & $>13,760$ \\
\hline
\end{tabular}

${ }^{\mathrm{z}} \mathrm{D}$ is the upper limit and $\mathrm{C}$ is the lower limit; ${ }^{\mathrm{y}} \mathrm{B}$ is the slope of the line; ${ }^{\mathrm{x}} \mathrm{I} 50$ is the rate where there is a $50 \%$ response; ${ }^{\mathrm{w}} \mathrm{ED}=\mathrm{the}$ rate of $2,4-\mathrm{D}$ choline/glyphosate DMA where there is $50 \%, 80 \%$ and $95 \%$ control; ${ }^{\mathrm{v}}$ Abbreviations: DAA, days after application; R1 and R2 are the two runs of this experiment.

fleabane was $190 \mathrm{~g} \cdot \mathrm{ae}_{\mathrm{ha}} \mathrm{h}^{-1}$ and $9624 \mathrm{~g} \cdot \mathrm{ae} \cdot \mathrm{ha}^{-1}$, respectively (Table 3). At 7 DAA, the rate of 2,4-D choline/ glyphosate DMA required to provide $50 \%$ control of the 20 and $30 \mathrm{~cm}$ tall Canada fleabane was $5132 \mathrm{~g} \cdot \mathrm{ae}^{-h^{-1}}$ and $5238 \mathrm{~g} \cdot \mathrm{ae} \cdot \mathrm{ha}^{-1}$, respectively (Table 4 and Table 5). These rates are higher than the highest rate of 2,4-D choline/glyphosate DMA applied in the greenhouse (3440 g·ae'ha ${ }^{-1}$ ). At 14 DAA, the rate of 2,4-D choline/glyphosate DMA providing 50\% control of the 10, 20 and $30 \mathrm{~cm}$ tall Canada fleabane was 645, 220 and 346 $\mathrm{g} \cdot \mathrm{ae} \mathrm{ha}^{-1}$, respectively (Tables 3-5). At 21 DAA, the rate of 2,4-D choline/glyphosate DMA required to provide $50 \%, 80 \%$ and $95 \%$ control of Canada fleabane that was $10 \mathrm{~cm}$ in height was 175, 1767 and $>13,760 \mathrm{~g} \cdot \mathrm{ae} \cdot \mathrm{ha}^{-1}$, respectively (Table 3). At 21 DAA, the plants that were $20 \mathrm{~cm}$ tall at the time of the application required rates of $271 \mathrm{~g} \cdot \mathrm{ae} \cdot \mathrm{ha}^{-1}$, $3444 \mathrm{~g} \cdot \mathrm{ae} \cdot \mathrm{ha}^{-1}$ and greater than $13,760 \mathrm{~g} \cdot \mathrm{ae} \cdot \mathrm{ha}^{-1}$ to provide $50 \%$, 80\% and 95\% control, respectively (Table 4). Where 2,4-D choline/glyphosate DMA was applied to $30 \mathrm{~cm}$ tall Canada fleabane, 21 DAA a rate of $965 \mathrm{~g} \cdot \mathrm{ae} \cdot \mathrm{ha}^{-1}$ was needed to provide $50 \%$ control, $4651 \mathrm{~g} \cdot \mathrm{ae} \cdot \mathrm{ha}^{-1}$ to provide $80 \%$ control and greater than 
13,760 g.ae $\cdot \mathrm{ha}^{-1}$ to provide $95 \%$ control (Table 5). Overall, at 21 DAA, a higher rate was required to control the larger Canada fleabane. These results are similar to Keeling et al. [17], who determined that higher rates of 2,4-D ester were needed to control larger Canada fleabane plants. At 35 DAA, similar rates of 2,4-D choline/glyphosate DMA provided 50\%, 80\% and 95\% control of the three sizes $(10,20$ and $30 \mathrm{~cm})$ of GR Canada fleabane. At 35 DAA, the I50 values for the 10, 20 and $30 \mathrm{~cm}$ tall plants were comparable, 638, 702 and 708, respectively (Tables $3-5$ ). The dry weight data provided slightly different results than the control ratings at 35 DAA. The I50 values for the dry weight data were diverse for the three sizes of Canada fleabane, 62 for the 10 $\mathrm{cm}, 1084$ for the $20 \mathrm{~cm}$ and 2499 when 2,4-D choline/glyphosate DMA was applied to $30 \mathrm{~cm}$ tall plants (Tables $3-5)$. According to the dry weight data the 20 and $30 \mathrm{~cm}$ tall plants required similar rates to provide $50 \%$ control $3305 \mathrm{~g} \cdot \mathrm{ae} \cdot \mathrm{ha}^{-1}$ and $3933 \mathrm{~g} \cdot \mathrm{ae} \cdot \mathrm{ha}^{-1}$, respectively, where the $10 \mathrm{~cm}$ tall Canada fleabane needed a lower rate of $143 \mathrm{~g} \cdot \mathrm{ae}^{-h^{-1}}$ to provide $50 \%$ control (Tables 3-5). To provide $80 \%$ and $95 \%$ control of the Canada fleabane according to the dry weight information a rate could not be determined for the $10 \mathrm{~cm}$ tall plants, but a rate higher than $13,760 \mathrm{~g} \cdot \mathrm{ae} \cdot \mathrm{ha}^{-1}$ was required to provide $80 \%$ or greater control of the $20 \mathrm{~cm}$ tall plants and for the plants $30 \mathrm{~cm}$ tall a rate of $8045 \mathrm{~g} \cdot \mathrm{ae} \cdot \mathrm{ha}^{-1}$ was needed to achieve $80 \%$ and a rate greater than $13,760 \mathrm{~g} \cdot \mathrm{ae}^{\mathrm{h}} \mathrm{ha}^{-1}$ was needed to provide $95 \%$ control. According to this dry weight data a lower rate controlled the $10 \mathrm{~cm}$ Canada fleabane plants, but the 20 and $30 \mathrm{~cm}$ tall plants required similar rates to provide $50 \%, 80 \%$ and $95 \%$ control of the GR Canada fleabane.

\subsection{Field Studies}

Regression analyses indicated that I50 and ED50, 80 and 95 values for the control ratings were similar for 2,4-D choline/glyphosate DMA applied to Canada fleabane at all three plant heights. At 1 week after the application (WAA) of 2,4-D choline/glyphosate DMA, control was similar for the three sizes of GR Canada fleabane. Injury symptoms ranged from slight twisting of the leaves with the lower rates of 2,4-D choline/glyphosate DMA to extreme twisting of the growing point with yellowing/browning of the leaf tips at the high rates. The I50 values 1 WAA of 2,4-D choline/glyphosate DMA on 10, 20 and $30 \mathrm{~cm}$ tall plants were 308 - 2411, 352 - 421 and 280 1675 g.ae ha $^{-1}$, respectively (Tables 6-8). The rates of 2,4-D choline/glyphosate DMA that provided $80 \%$ control of the GR Canada fleabane 1 WAA of 10, 20 and $30 \mathrm{~cm}$ tall GR Canada fleabane plants ranged from 1982 ->

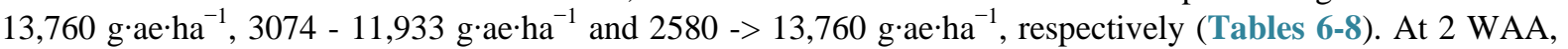
the rates of 2,4-D choline/glyphosate DMA that provided $50 \%$ and $80 \%$ control of the 10,20 and $30 \mathrm{~cm}$ tall Canada fleabane did not differ. At 2 WAA the rates of 2,4-D choline/glyphosate DMA that provided 50\% control of 10, 20 and $30 \mathrm{~cm}$ tall GR Canada fleabane were 368 - $584 \mathrm{~g} \cdot \mathrm{ae} \cdot \mathrm{ha}^{-1}, 271$ - $607 \mathrm{~g} \mathrm{~g} \cdot \mathrm{ae}^{\mathrm{h}} \mathrm{ha}^{-1}$ and 318 - 747 g.ae $\mathrm{ha}^{-1}$, respectively (Tables 6-8). At 4 WAA, the I50 values for the 10, 20 and $30 \mathrm{~cm}$ tall Canada fleabane were 359 - 625, 385 - 512 and 101 - 521 g·ae ha ${ }^{-1}$, respectively (Tables 6-8). The final control ratings, 8 WAA, for the three sizes of Canada fleabane had similar I50, ED50, 80 and 95 values and therefore the weed size at the time of application did not seem to affect the efficacy of 2,4-D choline/glyphosate DMA. At 8 WAA, the rate that provided $95 \%$ control of the $10 \mathrm{~cm}, 20 \mathrm{~cm}$ and $30 \mathrm{~cm}$ tall Canada fleabane was $952-11113 \mathrm{~g} \cdot \mathrm{ae}^{-\mathrm{ha}^{-1}}, 1835$ - $5737 \mathrm{~g} \cdot \mathrm{ae} \cdot \mathrm{ha}^{-1}$, and 1232 - $11391 \mathrm{~g} \cdot \mathrm{ae} \cdot \mathrm{ha}^{-1}$, respectively (Tables 6-8). Overall, these rates are very similar and the larger Canada fleabane did not appear to require a higher rate of 2,4-D choline/glyphosate DMA. However, a rate higher than $1720 \mathrm{~g} \cdot a \mathrm{ae} \cdot \mathrm{ha}^{-1}$ of 2,4-D choline/glyphosate DMA in some circumstances maybe required or tank mixed with another product to achieve 95\% control of GR Canada fleabane.

The I50 value and the ED50, 80 and 95 values for dry weight were lower at $30 \mathrm{~cm}$ than at the 10 or $20 \mathrm{~cm}$ application timings. For example, I50 value for 2,4-D choline/glyphosate DMA applied to $30 \mathrm{~cm}$ plants was 162 compared to 381 and 310 for the 10 and $20 \mathrm{~cm}$ tall plants, respectively. The application of 2,4-D choline/glyphosate DMA to GR Canada fleabane that was $30 \mathrm{~cm}$ in height had a lower ED50 (306 g.ae $\cdot \mathrm{ha}^{-1}$ ), ED80 (749 $\mathrm{g} \cdot \mathrm{ae} \cdot \mathrm{ha}^{-1}$ ) and ED95 (2908 g.ae $\cdot \mathrm{ha}^{-1}$ ) dry weight value compared to Canada fleabane that was $10 \mathrm{~cm}(705,1623$, $\left.5722 \mathrm{~g} \cdot \mathrm{ae}^{\circ} \mathrm{ha}^{-1}\right)$ or $20 \mathrm{~cm}\left(609,1976,13,207 \mathrm{~g} \cdot \mathrm{ae}^{-h^{-1}}\right)$ in height at the time of application (Tables 6-8). We speculate the reason for a lower ED50, 80 and 95 value for the dry weight data in the $30 \mathrm{~cm}$ timing is that newly emerging Canada fleabane was found in the 10 and $20 \mathrm{~cm}$ trial due to 2,4-D’s short soil residual activity and they were harvested [10]. The density data reflected the dry weight data showing that the GR Canada fleabane that was $10 \mathrm{~cm}$ in height at the time of application required a higher rate to achieve $50 \%$ and $80 \%$ control compared to Canada fleabane that was 20 or $30 \mathrm{~cm}$ tall, we again speculate that this was due to newly emerging Canada fleabane found in the early applications of 2,4-D choline/glyphosate DMA. Overall, applying 2,4-D 
Table 6. Rate response of the control of $10 \mathrm{~cm}$ Canada fleabane with 2,4-D choline/glyphosate DMA 1, 2, 4, 8 WAA and dry weight and density data 8 WAA for field trials in Ontario, Canada 2012 and 2013.

\begin{tabular}{|c|c|c|c|c|c|c|c|c|}
\hline Rate response $^{\mathrm{v}}$ & Locations & $\mathrm{D}^{\mathrm{z}}$ & $\mathrm{C}$ & $\mathrm{B}^{\mathrm{y}}$ & $150^{x}$ & $\mathrm{ED}^{2}{ }^{\mathrm{w}}$ & ED80 & ED95 \\
\hline \multirow[t]{4}{*}{$1 \mathrm{WAA}$} & L1 and L3 & $100(0)$ & $0.0(0)$ & $0.9(0)$ & 993 (31) & 993 & 4302 & $>13,760$ \\
\hline & L4 and L6 & $85(2)$ & $0(0)$ & $0.9(0.0)$ & 443 (35) & 671 & 10,732 & - \\
\hline & L2 & $100(0)$ & $3.4(2.6)$ & $0.6(0.0)$ & 2411 (345) & 2135 & 24,822 & $>13,760$ \\
\hline & L5 & 89 (1) & $0(0)$ & $1.2(0.1)$ & 308 (15) & 380 & 1982 & \\
\hline \multirow[t]{4}{*}{$2 \mathrm{WAA}$} & L1 and L3 & $94(1)$ & $0(0)$ & $1.2(0.1)$ & 398 (16) & 433 & 1215 & - \\
\hline & L2 and L4 & 99 (3) & $0.7(2.0)$ & $0.9(0.1)$ & $582(62)$ & 585 & 2938 & 20,394 \\
\hline & L5 & $93(2)$ & $0.6(2.2)$ & $1.5(0.1)$ & $298(20)$ & 368 & 1024 & - \\
\hline & L6 & $89(2)$ & $0(0)$ & $2.0(0.2)$ & 365 (19) & 479 & 1050 & - \\
\hline \multirow[t]{3}{*}{$4 \mathrm{WAA}$} & L1, L3 and L4 & $97(1)$ & $0(0)$ & $1.5(0.1)$ & 473 (20) & 494 & 1328 & 6391 \\
\hline & L5 and L6 & $100(1)$ & $2.8(1.4)$ & $1.8(0.1)$ & 359 (14) & 349 & 760 & 1836 \\
\hline & L2 & $100(0)$ & $5.5(1.6)$ & $1.4(0.1)$ & 625 (33) & 575 & 1590 & 4856 \\
\hline \multirow[t]{3}{*}{$8 \mathrm{WAA}$} & $\begin{array}{c}\text { L1, L2, L3 and } \\
\text { L5 }\end{array}$ & $99(0)$ & $0(0)$ & $1.0(0.1)$ & 503 (37) & 510 & 2085 & 11,113 \\
\hline & L4 & $100(0)$ & $0.5(0)$ & $0.9(0.1)$ & 256 (28) & 253 & 1169 & 6502 \\
\hline & L6 & $98(0)$ & $0(0)$ & $2.8(0.3)$ & $274(12)$ & 278 & 467 & 952 \\
\hline Dry weight & $\begin{array}{l}\text { L1, L2, L3, L4, } \\
\text { L5 and L6 }\end{array}$ & $99(0)$ & $0(0)$ & $1.1(0.1)$ & 381 (45) & 705 & 1623 & 5722 \\
\hline Density & $\begin{array}{l}\text { L1, L2, L3, L4, } \\
\text { L5 and L6 }\end{array}$ & $86(0)$ & $0(0)$ & $1.0(0.1)$ & 1244 (167) & 2131 & 5340 & - \\
\hline
\end{tabular}

${ }^{\mathrm{z}} \mathrm{D}$ is the upper limit and $\mathrm{C}$ is the lower limit; ${ }^{\mathrm{y}} \mathrm{B}$ is the slope of the line; ${ }^{\mathrm{x}} \mathrm{I} 50$ is the rate where there is a $50 \%$ response; ${ }^{\mathrm{w}} \mathrm{ED}=\mathrm{the}$ rate of glyphosate/2,4-D choline where there is $50 \%, 80 \%$ and $95 \%$ control; ${ }^{\mathrm{v}}$ Abbreviations: L1, L6, Windsor; L2, L3 and L5 are harrow; L4 is ridgetown; WAA, weeks after application.

Table 7. Field trials for the rate response of 2,4-D choline/glyphosate DMA for the control of $20 \mathrm{~cm}$ tall glyphosate resistant Canada fleabane 1, 2, 4, 8 WAA and the dry weight and density 8 WAA in Ontario, Canada in 2012 and 2013.

\begin{tabular}{|c|c|c|c|c|c|c|c|c|}
\hline Rate response $^{\mathrm{v}}$ & Locations & $\mathrm{D}^{\mathrm{z}}$ & $\mathrm{C}$ & $\mathrm{B}^{\mathrm{y}}$ & $150^{x}$ & $\mathrm{ED}^{2}{ }^{\mathrm{w}}$ & ED80 & ED95 \\
\hline \multirow[t]{3}{*}{$1 \mathrm{WAA}$} & L1, L6 & $84(2)$ & $0(0)$ & $0.8(0)$ & 352 (34) & 555 & 11936 & - \\
\hline & L2, L4 & $92(1)$ & $0(0.1)$ & $0.6(0)$ & 371 (90) & 486 & 7364 & - \\
\hline & L3, L5 & $87(1)$ & $0(0)$ & $1.2(0)$ & $422(16)$ & 537 & 3074 & - \\
\hline \multirow[t]{4}{*}{2 WAA } & L2, L3 & $91(2)$ & $0(0)$ & $1.3(0.1)$ & $524(28)$ & 607 & 2301 & - \\
\hline & L4, L5 & $92(0)$ & $0(0)$ & $0.7(0)$ & $227(21)$ & 290 & 3333 & - \\
\hline & L1 & $91(0)$ & $0(0.1)$ & $1.0(0.1)$ & $222(20)$ & 271 & 1594 & - \\
\hline & L6 & $100(0)$ & $0.3(0.1)$ & $0.8(0.0)$ & $578(56)$ & 578 & 3271 & $>13,760$ \\
\hline \multirow[t]{3}{*}{4 WAA } & L1, L4, L5 & $100(0)$ & $0(0)$ & $1.1(0)$ & $398(10)$ & 398 & 1347 & 5303 \\
\hline & L2, L6 & $100(0)$ & $0.4(0.1)$ & $1.1(0.1)$ & $512(32)$ & 508 & 1772 & 7198 \\
\hline & L3 & $100(0)$ & $0.2(0.1)$ & $1.6(0.1)$ & 385 (20) & 384 & 902 & 2357 \\
\hline \multirow[t]{3}{*}{8 WAA } & L1, L2, L4 & $100(0)$ & $2.0(1.6)$ & $1.2(0.1)$ & $502(27)$ & 485 & 1561 & 5737 \\
\hline & L5, L6 & $100(0)$ & $0(0)$ & $1.4(0.1)$ & $224(12)$ & 224 & 603 & 1835 \\
\hline & L3 & $100(0)$ & $0.8(0.1)$ & $1.8(0.1)$ & 365 (16) & 361 & 783 & 1862 \\
\hline Dry weight & $\begin{array}{l}\text { L1, L2, L3, L4, } \\
\text { L5 and L6 }\end{array}$ & $85(0)$ & $0(0)$ & $0.8(0.1)$ & 310 (65) & 609 & 1976 & 13,207 \\
\hline Density & $\begin{array}{l}\text { L1, L2, L3, L4, } \\
\text { L5 and L6 }\end{array}$ & 94 (5) & $0(0)$ & $0.8(0.1)$ & $308(71)$ & 681 & 2142 & 12,117 \\
\hline
\end{tabular}

${ }^{\mathrm{z}} \mathrm{D}$ is the upper limit and $\mathrm{C}$ is the lower limit; ${ }^{\mathrm{y}} \mathrm{B}$ is the slope of the line; ${ }^{\mathrm{x}} \mathrm{I} 50$ is the rate where there is a $50 \%$ response; ${ }^{\mathrm{w}} \mathrm{ED}=$ the rate of $2,4-\mathrm{D}$ choline/glyphosate DMA where there is 50\%, $80 \%$ and 95\% control; ${ }^{v}$ Abbreviations: L1, L6, windsor; L2, L3 and L5 are harrow; L4 is ridgetown; WAA, weeks after application. 
Table 8. Rate response of 2,4-D choline/glyphosate DMA on the control of $30 \mathrm{~cm}$ tall Canada fleabane 1, 2, 4, 8 WAA and dry weight and density 8 WAA conducted in field trials in 2012 and 2013 in Ontario, Canada.

\begin{tabular}{|c|c|c|c|c|c|c|c|c|}
\hline Rate response $^{\mathrm{v}}$ & Locations & $\mathrm{D}^{\mathrm{z}}$ & $\mathrm{C}$ & $\mathrm{B}^{\mathrm{y}}$ & $150^{x}$ & $\mathrm{ED}^{\mathrm{w}}{ }^{\mathrm{w}}$ & ED80 & ED95 \\
\hline \multirow[t]{4}{*}{$1 \mathrm{WAA}$} & L1, L2 & $91(2)$ & $0(0)$ & $0.8(0)$ & $496(30)$ & 640 & 6065 & - \\
\hline & L3, L5 & $88(1)$ & $0(0)$ & $1.2(0)$ & 417 (17) & 529 & 2966 & - \\
\hline & L4 & $82(3)$ & $0(0)$ & $0.8(0.1)$ & 675 (95) & 1190 & $>13,760$ & - \\
\hline & L6 & $96(0)$ & $0(0)$ & $0.7(0)$ & $280(27)$ & 312 & 2580 & $>13,760$ \\
\hline \multirow[t]{5}{*}{2 WAA } & L1, L5 & $87(2)$ & $0.9(1.4)$ & $1.2(0)$ & $528(32)$ & 675 & 4185 & - \\
\hline & L2 & $93(0)$ & $0(0.1)$ & $1.0(0.1)$ & 274 (29) & 318 & 1754 & - \\
\hline & L3 & $97(0)$ & $0(0.1)$ & $0.9(0)$ & 475 (49) & 510 & 2688 & $>13,760$ \\
\hline & L4 & $83(2)$ & $0(0)$ & $1.1(0.1)$ & $513(37)$ & 747 & 9855 & - \\
\hline & L6 & $100(0)$ & $0.4(1.6)$ & $1.0(0.0)$ & 365 (19) & 363 & 1323 & 5653 \\
\hline \multirow[t]{3}{*}{4 WAA } & L1, L3, L4, L5 & $100(0)$ & $0(0.1)$ & $0.8(0)$ & $521(39)$ & 521 & 2966 & $>13,760$ \\
\hline & L2 & $100(0)$ & $0(0.2)$ & $1.0(0)$ & $264(28)$ & 264 & 1021 & 4667 \\
\hline & L6 & $100(0)$ & $0(0.1)$ & $1.3(0.1)$ & $101(7)$ & 101 & 289 & 946 \\
\hline \multirow[t]{3}{*}{8 WAA } & L3, L4, L5 & $100(0)$ & $0(0)$ & $1(0)$ & $572(60)$ & 576 & 2308 & 11,391 \\
\hline & L2, L6 & $100(1)$ & $0.6(1.4)$ & $2.2(0.1)$ & $318(11)$ & 316 & 599 & 1232 \\
\hline & L1 & $98(2)$ & $0(0)$ & $1.4(0.1)$ & $411(26)$ & 420 & 1135 & 4087 \\
\hline Dry weight & $\begin{array}{l}\text { L1, L2, L3, L4, } \\
\text { L5 and L6 }\end{array}$ & 95 (4) & $0(0)$ & $1.0(0.1)$ & $162(21)$ & 306 & 749 & 2908 \\
\hline Density & $\begin{array}{l}\text { L1, L2, L3, L4, } \\
\text { L5 and L6 }\end{array}$ & $95(0)$ & $0(0.4)$ & $1.4(0.3)$ & 686 (98) & 1084 & 2086 & 5616 \\
\hline
\end{tabular}

${ }^{\mathrm{z}} \mathrm{D}$ is the upper limit and $\mathrm{C}$ is the lower limit; ${ }^{\mathrm{y}} \mathrm{B}$ is the slope of the line; ${ }^{\mathrm{x}} \mathrm{I} 50$ is the rate where there is a $50 \%$ response; ${ }^{\mathrm{w}} \mathrm{ED}=\mathrm{the}$ rate of $2,4-\mathrm{D}$ choline/glyphosate DMA where there is 50\%, $80 \%$ and 95\% control; ${ }^{\mathrm{v}}$ Abbreviations: L1, L6, windsor; L2, L3 and L5 are harrow; L4 is ridgetown; WAA, weeks after application.

choline/glyphosate DMA to larger Canada fleabane does not reduce the efficacy of this herbicide. These findings are similar to Kruger et al. [6], who reported the control of $30 \mathrm{~cm}$ tall Canada fleabane plants with 2,4-D ester was the same as when it was applied to rosette sized plants.

\section{Conclusion}

The efficacy of 2,4-D choline/glyphosate DMA for the control of GR Canada fleabane was not influenced by size $(10,20$ or $30 \mathrm{~cm}$ tall) of the Canada fleabane at the time of application in the field experiments. There were some differences in control of the three size classes of GR Canada fleabane in the greenhouse experiments, requiring a lower rate of 2,4-D choline/glyphosate DMA to control the $10 \mathrm{~cm}$ tall Canada fleabane compared to the 20 and $30 \mathrm{~cm}$ tall plants. However, similar rates of 2,4-D choline/glyphosate DMA provided $50 \%, 80 \%$ and $95 \%$ control of the 20 and $30 \mathrm{~cm}$ tall GR Canada fleabane in the greenhouse, which is comparable to the field experiments.

\section{References}

[1] Byker, H.P., Soltani, N., Robinson, D., Tardif, F., Lawton, M. and Sikkema, P.H. (2013) Occurrence of Glyphosate and Cloransulam Resistant Canada Fleabane (Conyza canadensis L. Cronq.) in Ontario. Canadian Journal of Plant Science, 93, 851-855. http://dx.doi.org/10.4141/cjps2013-039

[2] Kruger, G.R., Davis, V.M., Weller, S.C. and Johnson, W.G. (2010) Growth and Seed Production of Horseweed (Conyza canadensis) Populations after Exposure to Postemergence 2,4-D. Weed Science, 58, 413-419. http://dx.doi.org/10.1614/WS-D-10-00022.1

[3] Dauer, J.T., Mortensen, D.A. and Humston, R. (2006) Controlled Experiments to Predict Horseweed (Conyza canadensis) to Dispersal Distances. Weed Science, 54, 484-489. http://dx.doi.org/10.1614/WS-05-017R3.1 
[4] Shields, E.J., Dauer, J.T., VanGessel, M.J. and Neumann, G. (2006) Horseweed (Conyza canadensis) Seed Collected in the Planetary Boundary Layer. Weed Science, 54, 1063-1067. http://dx.doi.org/10.1614/WS-06-097R1.1

[5] Weaver, S.E. (2001) The Biology of Canadian Weeds. 115. Conyza Canadensis. Canadian Journal of Plant Science, 81, 867-875. http://dx.doi.org/10.4141/P00-196

[6] Cici, S.Z.H. and VanAcker, R.C. (2009) A Review of the Recruitment Biology of Winter Annual Weed in Canada. Canadian Journal of Plant Science, 89, 575-589. http://dx.doi.org/10.4141/CJPS08131

[7] Coupland, D. (1994) Resistance to the Auxin Analog Herbicides. In: Holtum, J.A.M. and Powlesm, S.B., Eds., Herbicide Resistance in Plants: Biology and Biochemistry, Lewis Publishers, Boca Raton, 171-214.

[8] Heap, I. (2014) The International Survey of Herbicide Resistant Weeds. www.weedscience.com

[9] Anonymous (2012) Technical Bulletin: A System Approach to Broad-Spectrum Weed Management for Corn, Soybeans and Cotton. Dow AgroSciences Publication, Indianapolis.

[10] Bolan, N.S. and Baskaran, S. (1996) Biodegradation of 2,4-D Herbicide as Affected by Its Adsorption-Desorption Behavior and Microbial Activity of Soils. Australian Journal of Soil Research, 34, 1041-1053. http://dx.doi.org/10.1071/SR9961041

[11] Bayley, C., Trolinder, N., Ray, C., Morgan, M., Quisenberry, J.E. and Ow, D.W. (1992) Engineering 2,4-D Resistance into Cotton. Theoretical and Applied Genetics, 83, 645-649. http://dx.doi.org/10.1007/BF00226910

[12] Storrie, A. (2014) Reducing Herbicide Spray Drift. NSW Agriculture. www.agric.nsw.gov.au

[13] Green, J.M. and Owen, M.D.K. (2010) Herbicide-Resistant Crops: Utilities and Limitations for Herbicide-Resistant Weed Management. Journal of Agricultural and Food Chemistry, 59, 5819-5829. http://dx.doi.org/10.1021/jf101286h

[14] Hillger, D.E., Qin, K., Simpsonand, D.M. and Havens, P. (2012) Reduction in Drift and Volatility of Enlist ${ }^{\mathrm{TM}}$ Duo $^{2}$ with Colex-D. Proceedings of the 65th Annual Meeting of the North Central Weed Science Society Conference Proceedings, 65, 38.

[15] Kruger, G.R., Davis, V.M., Weller, S.C. and Johnson, W.G. (2008) Response and Survival of Rosette-Stage HORSEWEED (Conyza canadensis) after Exposure to 2,4-D. Weed Science, 56, 748-752. http://dx.doi.org/10.1614/WS-08-059.1

[16] Kruger, G.R., Davis, V.M., Weller, S.C. and Johnson, W.G. (2010) Control of Horseweed (Conyza canadensis) with Growth Regulator Herbicides. Weed Technology, 24, 25-429. http://dx.doi.org/10.1614/WT-D-10-00022.1

[17] Keeling, W.J., Henniger, G.C. and Abernathy, J.R. (1989) Horseweed (Conyza canadensis) Control in Conservation Tillage Cotton (Gossypium hirsutum). Weed Technology, 3, 399-401.

[18] Bowley, S. (2008) A Hitchhiker’s Guide to Statistics in Plant Biology. 2nd Edition, Any Old Subject Books, Guelph, $266 \mathrm{p}$. 
Scientific Research Publishing (SCIRP) is one of the largest Open Access journal publishers. It is currently publishing more than 200 open access, online, peer-reviewed journals covering a wide range of academic disciplines. SCIRP serves the worldwide academic communities and contributes to the progress and application of science with its publication.

Other selected journals from SCIRP are listed as below. Submit your manuscript to us via either submit@scirp.org or Online Submission Portal.
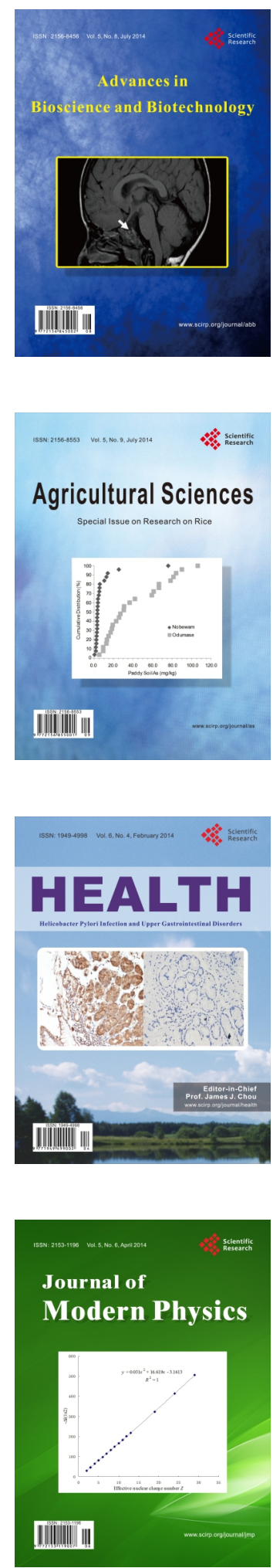
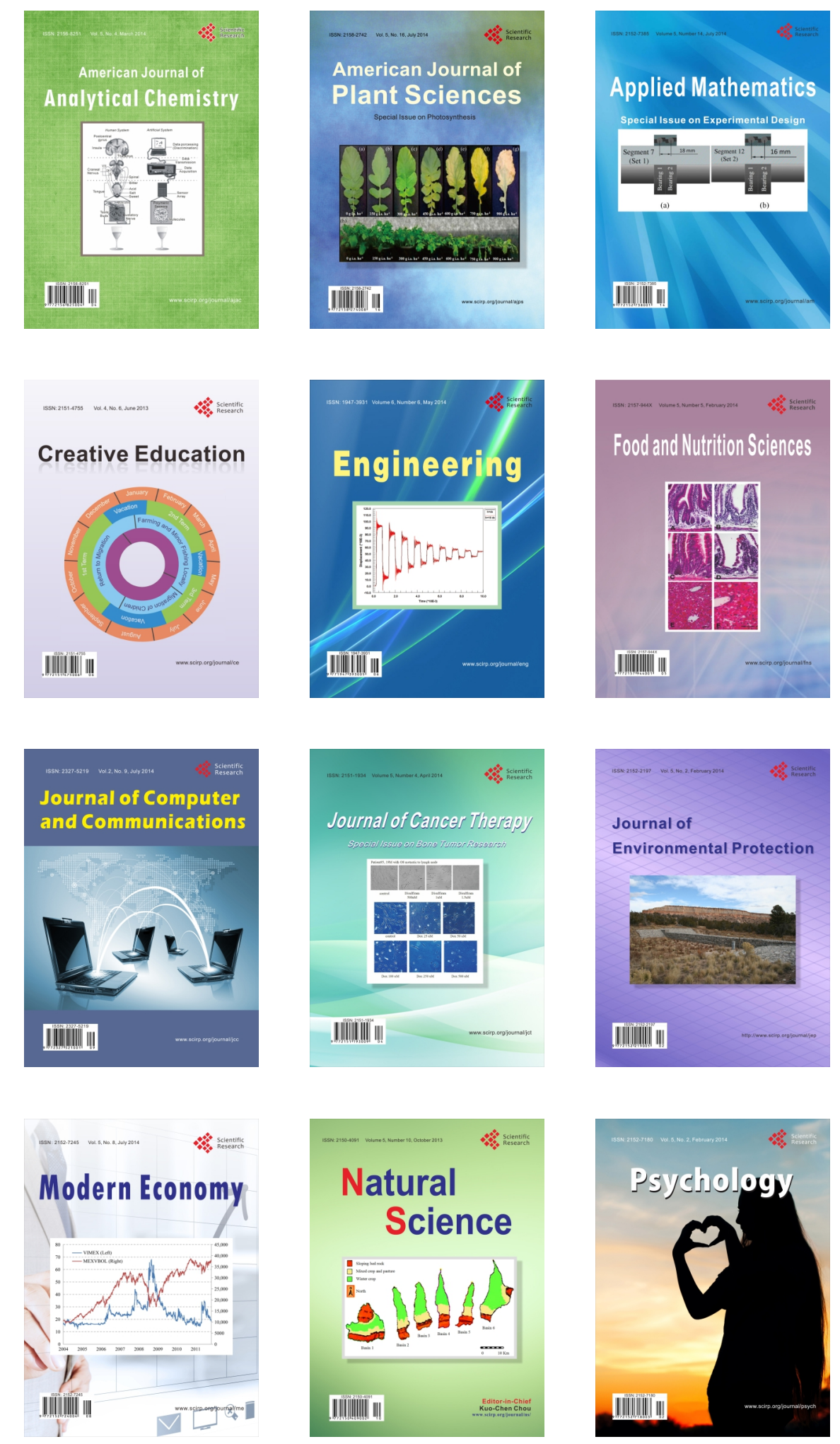